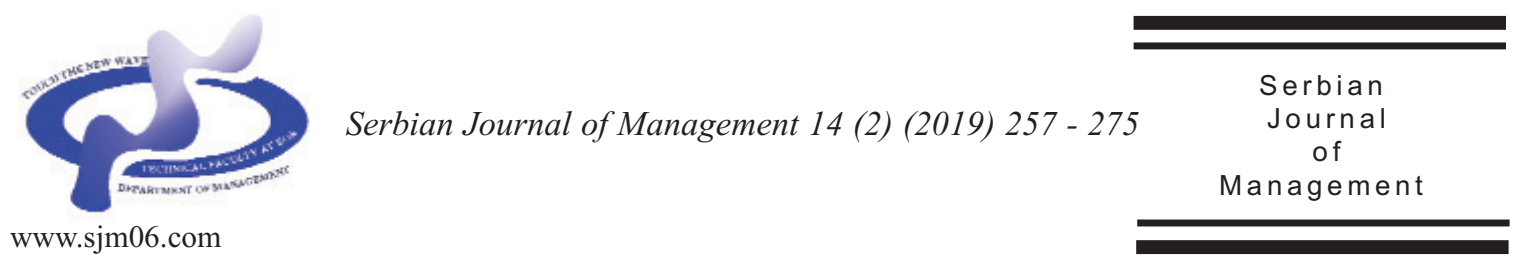

\title{
EXPLAINING BUSINESS FAILURE THROUGH DETERMINIST AND VOLUNTARIST PERSPECTIVES
}

\author{
Gentjan Çera*, Jaroslav Belas and Eliska Zapletalikova \\ Tomas Bata University in Zlin, Faculty of Management and Economics, \\ Mostní 5139, 76001 Zlín, Czech Republic
}

(Received 30 September 2019; accepted 20 October 2019)

\begin{abstract}
The aim of this study is to investigate factors that can prevent business failure by using determinist and voluntarist perspectives collectively. Both views implicate numerous theories such as institutional theory, industry life cycle theory, resource-based view, emotive approach etc. This research is conducted on a firm-level data collection through a survey. The current study uses principal component analysis and hierarchical logistic regression to test the proposed hypotheses in an original dataset of small and medium-sized enterprises (SMEs) operating in Central Europe. The results demonstrated that facing institutional constraints and internal difficulties can lead to business failure. Firms in growth phase of business cycle are less likely to fail as compared to their counterparts in establishment phase. At the individual level, having entrepreneurial experience diminished the business failure. Moreover, failure is less prone to occur for bigger firms and those that operate as business-to-business (B2B). The current research contributes to enriching the literature of the field by offering evidence on how to avoid failure. This paper provides useful insights for both managers and policymakers who are responsible for designing policies and strategies to boost entrepreneurship.
\end{abstract}

Keywords: business failure, institutional constraints, business cycle, internal resources, psychological motives, entrepreneurial experience

\section{INTRODUCTION}

Entrepreneurship is widely recognized as an important engine of the economy, as it reduces the unemployment rate and contributes to economic growth
(Abdesselam et al., 2018; Acs et al., 2018; Bosma et al., 2018). Therefore, society benefits from entrepreneurship at least in two aspects: social and economic. In this context, there are reports that emphasize the contributions of small and medium-sized

\footnotetext{
* Corresponding author: cera@utb.cz
}

DOI: $10.5937 /$ sjm14-23348 
enterprises (SMEs) to the economy covering the European Union (EU) counties (European Commission, 2018). According to the latter reports, 66 out of 100 employees in the EU non-financial business sector work for SMEs. On the other hand, SMEs operating in the EU generated, on average, more than half of value-added (56.8\%) in 2018. Almost similar figures are recorded even for the Central European countries (such as Czech Republic and Hungary). Regarding the Serbian case, the above figures resulted a bit lower than the average of EU. Hence, number of people employed in SME sector was 7\% lower than the average of $\mathrm{EU}$, and contribution to value added was $8 \%$ less than the EU average.

The above figures demonstrate why scholars, policymakers and government have a constant interest in SME's 'health'. If they reflect a better performance, then their contribution to the economy will be higher. In this context, there is a need to investigate factors that drive firm performance, survival and failure. The aim is to reduce as much as possible the chances of organizational failure (Kliestik et al., 2018). In this regard, it is of high interest to study business termination, in general, and to understand which factors affect it, in particular. By doing so, scholars, policymakers and government may adjust the existing policies, strategies, instruments, regulatory framework etc., aiming improvement of business environment.

Among scholars and experts, it is commonly known the fact that entrepreneurial activity is threated by different sort of risks that may cause even business termination (Falkner \& Hiebl, 2015; Brachert et al, 2017; Valaskova et al., 2018).

When a crisis is present or in times of vague economic growth, interest in understanding factors that cause business decline and failure is growing (Kücher \& Feldbauer-Durstmüller, 2019). Business success or termination cannot be explained just by investigating the effect of internal organization factors, but also external ones (Shepherd et al., 2019). In this regard, the current research aims to study the effect of both external and internal factors collectively on business failure. Determinants of business failure can be investigated through determinist (factors outside from the organisation) (Swaminathan, 1996) and voluntarist (factors within the organisation) (Van Gelder et al, 2007) perspectives.

The rest of the article is organized as follow. Next section is dedicated to the theoretical background and hypotheses development. Then, the applied methods and followed procedures are described. In section four are given the results of the analysis, and in the next section, they are discussed. Finally, the paper ends by elaborating the theoretical and practical implication of this research.

\section{LITERATURE REVIEW}

A burgeoning literature is growing on the determinants, consequences, context and environment of business failure (Walsh \& Cunningham, 2016; Dias \& Teixeira, 2017; García-Ramos et al., 2017; Karabag, 2019; Martinez et al., 2019). In general, business failure research can be grouped into three major streams: (i) prediction models, (ii) finance and law, and (iii) organizational failure (Kücher \& Feldbauer-Durstmüller, 2019). However, another research subfield is recently burgeoning covering perceptions, consequences and cost of business failure (Ucbasaran et al., 2013). The current 
research is under the third theme, since its aim is to explore factors which determine business failure.

Organisational failure is explained mainly through two dominant perspectives: determinist (Swaminathan, 1996) and voluntarist (Van Gelder et al., 2007). According to the determinist perspective, organisational failure is caused by factors originated from outside of the firm over which managers do not have the power to influence or manipulate. This perspective implicates numerous theories, including institutional theory (North, 1990) and industry life cycle theory (Klepper, 1997). The institutional theory assumes that institutional environment may constrain business activity, or cause even organisational failure. The industry life cycle theory claims that business failure can be a result of shortage in supply, demand saturation or innovation (a new technology) that has the capacity to offer more value (Mellahi \& Wilkinson, 2004).

On the other hand, based on the voluntarist perspective, firm termination is a function of factors originated from within the organisation over which managers have the power to control, such as poor leadership and mismanagement. The voluntarist perspective implicates several theories, including resource-based view (Barney, 1991) and discrepancy theory (Cooper \& Artz, 1995). The resource-based view claims that organization has the capacity to combine its resources to achieve higher results. In the literature the notion of "entrepreneurial satisfaction" is presented by discrepancy theory to measure the psychology of one entrepreneurial success which might have an important role on one's decision concerning business continuance or termination.

\subsection{Institutional environment}

As mention above, the institutional environments are factors outside entrepreneurs' control and can cause even organization failure. Therefore, institutional constraints shape entrepreneur behaviour (North, 1990). Such factors could be political, legal, regulatory frameworks, or cultural and social norms. The complexity of legislation and cumbersome regulation expose firms to default risk. A study showed that between economic policies and firms' satisfaction there is an association (Blume, 2006). Thus, entrepreneurship can be fostered by business enabling policies and impeded by heavy regulations (Çera et al., 2019b).

Culture and social norms along with legislation and regulatory framework, create the conditions for the individual to make decisions, which is vital in entrepreneurial cognition (Sobel, 2008; Pinho, 2017; Raza et al., 2018). As Douhan and Henrekson (2010) advocate, institutional environments have the ability to determines the type of business activity: productive, unproductive or destructive. Thus, a hypothesis can be formulated:

Hypothesis 1 (H1): There is a positive relationship between institutional constraints and business failure.

\subsection{Business cycles}

Besides institutional environments, economic conditions where firms operate may boost or constrain entrepreneurship. The business climate is not just a function of institutional constraints, but it is also a function of economic factors (such as economic situation, macroeconomic 
indicators etc.). This is covered by economic development perspective (Wennekers et al., 2005), which suggest that economies with different levels of development are expected to have different effects on entrepreneurial activity.

According to the industry life cycle theory (Klepper, 1997), organizations follow a priori sequence independent of their strategies and management. Similar to products, firms follow the same life cycle with four stages: establishment (fragmentation), growth (shakeout), stagnation (maturity) and decline (Mellahi \& Wilkinson, 2004). During the economic growth, internal resources, as well as micro and macro environment factors, are unused (Bienkowska-Golasa, 2018). According to Rauch and Rijsdijk (2013), growth in employment negatively influences business failure. Usually, firms increase the number of employees in times of growth or shakeout stage of business cycle. This discussion leads to the linkages between business cycles and business failure. Based on the above discussion, in light of the determinist perspective, a new hypotheses can be formulated:

Hypothesis 2 (H2): There is an association between business cycles and organisation failure (firms are less prone to fail during the growth phase of the business cycle).

\subsection{Internal resources}

The resource-based view suggests that by combining internal resources better results can be achieved (Barney, 1991). Internal resources include organizational processes, assets, firm attributes, capabilities, knowledge, etc., controlled by an organisation that gives the opportunity to harmonize or combine them by implementing strategies aiming its effectiveness and efficiency. Thus, limited assets and inefficient management of them limits the possibilities of achieving higher performance. In this context, human resources can play a special role as they are an engine of the business activity (Stacho et al., 2017). Furthermore, the way how processes are designed influence all business aspects. A not easy-follow of organizational processes may decrease the firm performance. When these internal resources are well-combined it leads to better performance, otherwise they may constrain the activity until its termination. Therefore, there is a linkage between internal resources and business failure.

Hypothesis 3 (H3): Firms that face internal problems (poor leadership and mismanagement) are more likely to fail.

\subsection{Emotive approach}

Contrary to the abovementioned theoretical backgrounds (institutional theory, industry life cycle theory, resource-based view), the emotive approach, rooted in discrepancy theory (Cooper \& Artz, 1995), assumes that psychological aspects might influence on business performance and yet when they are negative attitude, emotions etc., may lead to business failure (Khelil, 2016; Solaja et al., 2016; Lačný et al., 2018; Nikolić et al., 2019). Sometimes these factors are more important than environmental or organizational factors regarding business termination (Van Gelder et al., 2007). Scholars who used the emotive approach demonstrated that individual-level factors contribute to explaining business 
failure. Thus, psychological factors can cause organization failure (Van Gelder et al., 2007). Economically motivated individuals, including entrepreneurs, are then less satisfied (Cooper \& Artz, 1995) and accordingly more prone to terminate their business. Therefore,

Hypothesis 4 (H4): A fall in psychological motives can lead to the failure of the organisation.

\subsection{Entrepreneurial experience}

In the line with the emotive approach, there are other factors at individual-level that influence on business survival or failure such as managerial and/or entrepreneurial experience (Ucbasaran et al., 2010). Facing different problems, owners or managers can gain extra knowledge on dealing with them in business activity. Indeed, a study found that having experiences of failure and learning from failure positively affect new venture performance (Boso et al., 2019). In addition, Gagoitseope and Pansiri (2012) demonstrated that there is a positive linkage between one's years in business and motivation. Therefore, having experiences in business can reduce failure chances of an organisation. This lead to a new hypothesis:

Hypothesis 5 (H5): There is a negative linkage between entrepreneurial experience (years in business) and business failure.

\subsection{Firm characteristics and country}

Besides the abovementioned factors, there are other firm-level factors that may cause business termination, such as firm age, size and type of its main commercial transactions. Firm characteristics are seen as potential factors that may influence on business performance or cause even its failure (Pansiri \& Temtime, 2010; Ucbasaran et al., 2010; Sauka \& Welter, 2014). Below are explained the linkages between firm characteristics and business failure.

Scholars have demonstrated an inverse relationship between firm age and business failure (Mellahi \& Wilkinson, 2004). Indeed, there is evidence supporting this association (Iwanicz-Drozdowska et al., 2018). The older a firm, the less likely its fail to occur. It seems that, in comparison to new firms, organizations having many years operating in business have gained experience to adapt to different situation that threatens their continuance or survival. Thus, the following hypothesis is framed:

Hypothesis 6 (H6): Older firms are expected to have fewer chances to fail, as compared to younger ones.

Similar to firm age, the size of business positively influence business survival (El Kalak \& Hudson, 2016) or growth (Yamakawa et al., 2015). Consequently, the larger the business, the more prone its continuance, and the fewer chances its termination (Martinez et al., 2019). It seems that bigger firms have more opportunities to adapt to situations which may cause their failure. Indeed, larger firms can reorganise its processes, assets and human resources in way to survive easier than their small counterparts. Thus, a linkage between firm size and business failure can be assumed.

Hypothesis 7 (H7): Compare to small firms, larger ones are less likely to fail.

The main type of commercial transactions of a firm may influence its performance and 
survival. There are three main types of those transactions: business-to-consumer (B2C), business-to-business (B2B), and both to consumers and business (B2C\&B). According to Munoz and Kumar (2004), firms as B2B have an important advantage, as they know their consumers and can notice different signals and dynamics originated from the market, as compared to B2C. This means that firms operating with other firms (B2B) are less likely to fail compared to B2C. Based on the above discussion, a new hypothesis is proposed:

Hypothesis 8 (H8): Businesses that have as the main commercial transactions with other businesses (B2B) are less likely to fail, as compare to those firms that have these transactions with consumers (B2C).

Among scholars it is recognised that entrepreneurship differs among countries in terms of new entrepreneurial rate, performance and exit (Ucbasaran et al., 2013; Guerrero et al., 2016; Dheer, 2017; García-Ramos et al., 2017; Dilli \& Westerhuis, 2018; Eling \& Jia, 2018; Tingbani et al., 2019). According to Stam
(2009), the location where the behaviours take place plays an important role in the start-up and entrepreneurial activities. The latter is supported even by other studies, such as with Vaillant and Lafuente's (2007) study. According to a study, in comparison with Slovak graduate students, Czech ones manifested a lower interest in start-up activity (Çera et al., 2018). Taking all together, the firm failure rate varies across countries. Thus,

Hypothesis 9 (H9): The business failure differs across countries.

Figure 1 shows the conceptual framework of the current research. As discussed in the literature review, business failure can be explained by two major domains: determinist (Swaminathan, 1996) and voluntarist (Van Gelder et al., 2007) perspectives. They imply several theories such as institutional theory, industry life cycle theory, resource-based view, discrepancy theory. Besides them, firm characteristics can influence firm failure.

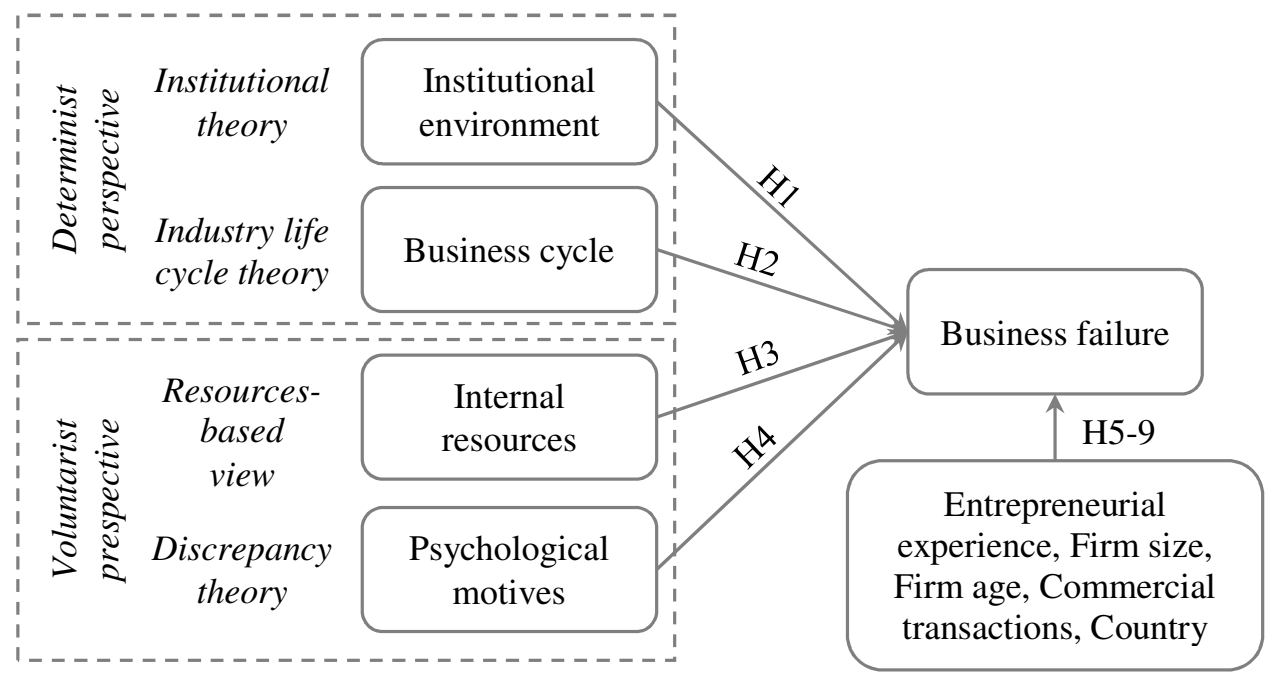

Figure 1. Theoretical model 


\section{METHODS AND PROCEDURES}

\subsection{Unit of analysis and data collection}

To test the proposed hypotheses in the theoretical model (see Figure 1), initially a questionnaire in the English language was developed and then its content validity was revised by academics. Next, it was translated into three local languages, Czech, Hungarian and Serbian. The questionnaire has been chosen as the data collection technique because prior studies in this field have employed the same tool (Nikolić et al., 2019). The questionnaire contained two main sections: indicators for the institutional environment and internal resources, and general information concerning firm and owner/manager's characteristics.

A pilot test with firms was conducted, to be able to revise the accuracy of the translation and to ensure consistency. These records were deleted from the final sample. The data collection phase took place from February to June 2019. The firms were approached via email asking them to fill out the online questionnaire, with the possibility to answer only one time. The final sample reached 329 valid records.

Table 1 reports the profile of the sample. Close to half of the respondents were firms under 3 years and between 3 and 5 years of operation in the market in the time of financial distress, whereas $54.77 \%$ of them had more than 5 years. Almost half of the firms had more than 5 employees (46.81\%), and just above the half were those firms with less than 5 employees (53.19\%). Approximately, four in ten respondents (43.21\%) closed the business, while the rest either changed the production with different products $(23.46 \%)$, or started to develop new products $(33.33 \%)$.

In Table 2 are described the measurement of the current study's variables. The dependent variable is business failure, measured as a dichotomous variable. The others were such as dichotomous, nominal, ordinal, scale and Likert scale. The latter variable type was used to measure the indicators of institutional environment and internal resources. To reduce the huge

Table 1. Sample profile

\begin{tabular}{llcc}
\hline \multicolumn{1}{c}{ Category } & \multicolumn{1}{c}{ Sub-category } & N & Share \\
\hline \multirow{4}{*}{ Country } & Czech Republic & 95 & $28.88 \%$ \\
& Hungary & 100 & $30.40 \%$ \\
& Serbia & 134 & $40.73 \%$ \\
& Total & 329 & $100 \%$ \\
\hline \multirow{3}{*}{ Firm age in the time of } & Under 3 years & 89 & $27.38 \%$ \\
financial distress & Between 3 and 5 years & 58 & $17.85 \%$ \\
& More than 5 years & 178 & $54.77 \%$ \\
\multirow{2}{*}{ Firm size at the moment of } & Total & 325 & $100 \%$ \\
\hline financial distress & Mors than 5 employees & 175 & $53.19 \%$ \\
& Total & 154 & $46.81 \%$ \\
\multirow{3}{*}{ Did you close your business? } & I closed the business & 329 & $100 \%$ \\
& I started to develop new products & 140 & $43.21 \%$ \\
& Total & 76 & $23.46 \%$ \\
& & 108 & $33.33 \%$ \\
& & 324 & $100 \%$ \\
\hline
\end{tabular}


number of factors (indicators), factor analysis was employed, which is described in the following paragraphs. Given that firm age and size, location, commercial transactions, entrepreneurial experience and business cycle have been found to have a significant influence on firm performance and failure, they were included in the analysis.

Constraint factors were measured using fourteen statements dealing with the institutional environment and internal resources, as indicated by the institutional theory (North, 1990) and resource-based view (Barney, 1991). A firm's representative was asked to give his firm perception on these statements (see Table 3). The central question was: To what extent the following factors created difficulties to your business that failed? The statements' responses were formulated as five-point Likert type scale (1 $=$ lowest, $5=$ highest). Exploratory factor analysis was used to reduce this number of indicators (Fabrigar \& Wegener, 2011). The principal component analysis was selected as extracted method. Varimax with Kaiser normalization was applied as rotation method. The output of the analysis is reported in Table 3. Factors with eigenvalues higher than one, were kept. The KaiserMeyer-Olkin value was greater than the conservative value of 0.70 and Barlett's test of sphericity was significant, showing evidence of the appropriateness of the factor analysis (Hair et al., 2014). Five factors emerged from the factor analysis, which explained $64.81 \%$ of the variance in the sample. The factor loadings were nicely above Stevens's and Pituch's (2015) criteria (value of 0.40), showing evidence of constructs convergent validity. No problems with commonalities were noticed.

The second and third factors were loaded by indicators originated from the institutional environment, whereas the others were created by indicators originated from within the organization (internal resources). Even though factor analysis extracted five

\section{Table 2. Variable measurement}

\begin{tabular}{lll}
\hline \multicolumn{1}{c}{ Variable } & \multicolumn{1}{c}{ Type } & \multicolumn{1}{c}{ Measure } \\
\hline $\begin{array}{l}\text { Business failure } \\
\text { (dependent variable })\end{array}$ & Dichotomous & $\begin{array}{l}\text { As the result of financial distress, did you close your business? } \\
\text { [0] No; [1] Yes. }\end{array}$ \\
\hline Country & Nominal & $\begin{array}{l}\text { Where do you operate? } \\
\text { [1] Czech Republic; [2] Hungary; [3] Serbia. }\end{array}$ \\
\hline Firm size & Dichotomous & $\begin{array}{l}\text { The number of employees at the moment of financial distress } \\
\text { was: [0] Less than 5 employees; [1] More than 5 employees. }\end{array}$ \\
\hline $\begin{array}{l}\text { Firm age } \\
\text { financial distress }\end{array}$ & Ordinal & $\begin{array}{l}\text { Firm age of the company in the time of financial distress: } \\
\text { [1] Less than 3 years; [2] Between 3 and 5 years; [3] More than } \\
\text { 5 years. }\end{array}$ \\
\hline $\begin{array}{l}\text { Commercial } \\
\text { transactions }\end{array}$ & Nominal & $\begin{array}{l}\text { Who were the customers of your previous firm? } \\
\text { [1] Individuals (business to consumers, B2C); [2] Other firms } \\
\text { (business to business, B2B); [3] Both (B2C \& B2B). }\end{array}$ \\
\hline $\begin{array}{l}\text { Entrepreneurial } \\
\text { experience }\end{array}$ & Scale & $\begin{array}{l}\text { Number of years working for the firm at the time of financial } \\
\text { crisis }\end{array}$ \\
\hline Business cycle & Nominal & $\begin{array}{l}\text { Business life cycle in the time of financial distress: } \\
\text { [1] Establishment; [2] Growth; [3] Stagnation; [4] Decline. }\end{array}$ \\
\hline $\begin{array}{l}\text { External and internal } \\
\text { factors }\end{array}$ & Likert scale & $\begin{array}{l}\text { To what extent the following factors (see Table 3) created } \\
\text { difficulties to your business? } \\
\text { [1] 'Lowest' to [5] 'Highest'. }\end{array}$ \\
\hline
\end{tabular}


Table 3. Rotated component matrix

\begin{tabular}{|c|c|c|c|c|c|c|}
\hline \multirow{2}{*}{ Items and composed factors } & \multicolumn{5}{|c|}{ Component } & \multirow{2}{*}{$\begin{array}{c}\text { Commu- } \\
\text { nalities }\end{array}$} \\
\hline & 1 & 2 & 3 & 4 & 5 & \\
\hline \multicolumn{7}{|l|}{ Internal resources 1} \\
\hline The level of fixed assets free from any burden/inscription & 0.787 & & & & & 0.709 \\
\hline The level of clearing/ barter transaction & 0.775 & & & & & 0.696 \\
\hline Inability to find new potential shareholders/partner & 0.697 & & & & & 0.557 \\
\hline \multicolumn{6}{|l|}{ technologies/innovation } & 0.573 \\
\hline \multicolumn{7}{|l|}{ Institutional environment 1} \\
\hline Political issues & & 0.729 & & & & 0.556 \\
\hline Economic issues & & 0.714 & & & & 0.596 \\
\hline Social issues & & 0.641 & & & & 0.561 \\
\hline Legislative issues & & 0.559 & & & & 0.565 \\
\hline \multicolumn{7}{|l|}{ Institutional environment 2} \\
\hline Ecological issues & & & 0.798 & & & 0.711 \\
\hline Technological issues & & & 0.760 & & & 0.656 \\
\hline \multicolumn{7}{|l|}{ Internal resources 2} \\
\hline Delay in fulfilling bank obligations & & & & 0.850 & & 0.796 \\
\hline Management of receivables/payables & & & & 0.797 & & 0.745 \\
\hline \multicolumn{7}{|l|}{ Psychological motives } \\
\hline Fall of motivation & & & & & 0.857 & 0.750 \\
\hline Delegation of responsibilities & & & & & 0.661 & 0.602 \\
\hline Eigenvalues & 3.861 & 1.795 & 1.294 & 1.103 & 1.020 & \\
\hline Explained variance $(\%)($ total $=64.81 \%)$ & 15.8 & 13.9 & 12.9 & 11.7 & 10.6 & \\
\hline Cronbach's alpha & 0.74 & 0.70 & 0.63 & 0.71 & 0.56 & \\
\hline
\end{tabular}

factors, two of them resulted with low level of scale reliability. Therefore, "institutional environment 2" and "psychological motives", which correspond to the third and fifth components of the factor analysis, were not considered in further analysis steps, because of low Cronbach's alpha values $(<$ 0.70) (Hair et al., 2014). The deletion of the last factor means that it is not possible to investigate the effect of psychological motives on business failure ( Cooper \& Artz, 1995; Van Gelder et al., 2007; Khelil, 2016). Therefore, it was not possible to tests H4. Both, the first component "internal resources 1 " and second component "institutional environment 1 " were result of four indicators each, while the fourth component "internal resources 2" was loaded by two indicators dealing with delay in fulfilling bank obligations and management of receivables/payables. The latter components were kept and used in further analysis processes.

The nature of the dependent variable (dichotomous variable) limits the use of the statistical methods. Thus, hierarchical logistic regression was performed to explore the effect of institutional and internal factors along with firm characteristics on business failure (Hosmer, et al., 2013; Tabachnick \& Fidell, 2013). A similar method was used even by Rauch and Rijsdijk (2013). The analyses were executed using SPSS version 23. 


\section{RESULTS}

To investigate the effect of the external and internal organisation's factors collectively on business failure, a hierarchical logistic regression with two steps was performed. The dependent variable was business failure (Yes/No). The first step of the model (baseline model), includes only control variables such as firm age and size, country where firm operates, type of commercial transactions, business cycle and entrepreneurial experience of the owner/manager. The second step, in addition to the control variables, includes two factors related to internal resources and one related to institutional environment, as extracted from factor analysis. The results are presented in Table 4.

The baseline model demonstrated that excluding firm age $\left(\chi^{2}=1.297, p>0.10\right)$ and entrepreneurial experience $\left(\chi^{2}=2.133\right.$, $\mathrm{OR}=0.968, \quad p>0.10)$, all other control variables significantly influence on business failure (see Table 4). Compared to Serbian firms, those from the Czech Republic had fewer chances to fail, as the odds ratio was reported less than one, $\chi^{2}=7.101, \mathrm{OR}=0.415$,

Table 4. Results of the hierarchical logistic regression

\begin{tabular}{|c|c|c|c|c|c|c|c|c|}
\hline & \multicolumn{4}{|c|}{ Baseline model } & \multicolumn{4}{|c|}{ Full model } \\
\hline & B & SE & OR & Wald & B & SE & OR & Wald \\
\hline Constant & 1.223 & 0.579 & 3.396 & $4.453 * *$ & 1.257 & 0.588 & 3.514 & $4.575 * *$ \\
\hline Country & & & & $11.53 * * *$ & & & & $10.30 * * *$ \\
\hline Czech Republic & 0.247 & 0.325 & 1.280 & 0.579 & 0.263 & 0.377 & 1.301 & 0.487 \\
\hline Hungary & -0.880 & 0.330 & 0.415 & $7.101 * * *$ & -0.839 & 0.342 & 0.432 & $6.031 * *$ \\
\hline Firm size & -0.905 & 0.273 & 0.404 & $10.97 * * *$ & -0.890 & 0.28 & 0.411 & $10.14 * * *$ \\
\hline Firm age financial distress & & & & 1.297 & & & & 1.452 \\
\hline Under 3 years & -0.057 & 0.428 & 0.945 & 0.018 & -0.111 & 0.439 & 0.895 & 0.065 \\
\hline Between 3 and 5 years & -0.431 & 0.408 & 0.650 & 1.113 & -0.476 & 0.413 & 0.621 & 1.331 \\
\hline Commercial transactions & & & & 4.209 & & & & 3.430 \\
\hline$B 2 B$ & -0.762 & 0.393 & 0.467 & $3.765 *$ & -0.706 & 0.398 & 0.494 & $3.140 *$ \\
\hline$B 2 C \& B$ & -0.076 & 0.296 & 0.927 & 0.065 & -0.093 & 0.303 & 0.911 & 0.094 \\
\hline Entrepreneurial experience & -0.032 & 0.022 & 0.968 & 2.133 & -0.036 & 0.023 & 0.964 & $2.591 \star$ \\
\hline Business cycle & & & & $6.534 *$ & & & & 5.604 \\
\hline Growth & -0.917 & 0.463 & 0.400 & $3.922 * *$ & -0.891 & 0.471 & 0.410 & $3.578 *$ \\
\hline Stagnation & -0.116 & 0.476 & 0.891 & 0.059 & -0.162 & 0.484 & 0.851 & 0.111 \\
\hline Decline & -0.173 & 0.490 & 0.841 & 0.125 & -0.157 & 0.497 & 0.855 & 0.099 \\
\hline Internal resources 1 & & & & & -0.224 & 0.142 & 0.799 & 2.480 \\
\hline Institutional environment 1 & & & & & 0.242 & 0.144 & 1.274 & $2.822 *$ \\
\hline Internal resources 2 & & & & & 0.219 & 0.132 & 1.245 & $2.757 *$ \\
\hline Additional statistics & Stat. & $\chi^{2}$ & $\mathrm{df}$ & Sig. & Stat. & $\chi^{2}$ & $\mathrm{df}$ & Sig. \\
\hline Omnibus test & & 55.42 & 11 & 0.000 & & 64.21 & 14 & 0.000 \\
\hline Hosmer \& Lemeshow test & & 13.88 & 8 & 0.085 & & 6.093 & 8 & 0.637 \\
\hline -2Log likelihood & 354.7 & & & & 345.9 & & & \\
\hline Cox \& Snell R-square & 0.170 & & & & 0.194 & & & \\
\hline Nagelkerke R-square & 0.227 & & & & 0.259 & & & \\
\hline
\end{tabular}


$p<0.01$. Thus, country where firms operate affect business termination, $\chi^{2}=11.53$, $p<0.01$. Firms with less than five employees resulted to have higher possibilities to business failure, as compared to those with more than five employees, $\chi^{2}=10.97$, $\mathrm{OR}=0.404, \quad p<0.01$. Firms with $\mathrm{B} 2 \mathrm{~B}$ commercial transactions had lower changes to fail, compared to $\mathrm{B} 2 \mathrm{C}, \chi^{2}=3.765$, $\mathrm{OR}=0.404, p<0.01$. The business cycle in the time of financial distress was found to be a significant predictor of business failure, $\chi^{2}=6.534, p<0.10$. Indeed, compared to establishment phase, those that were in growth phase of business life cycle had lower possibilities to fail, $\chi^{2}=3.922, \mathrm{OR}=0.4$, $p<0.05$.

In the second step of the hierarchical logistic regression, two other categories of variables were included: two variables dealing with internal resources and one pointing to the institutional environment. Hence, this step of the logistic regression includes all variables and it is named as 'full model' (see Table 4). This step of logistic regression revealed that institutional environment and one of the internal resources variables predicted business failure. In this regard, the chances a business exposes to failure increased as the perception of institutional environment constraint increased, $\chi^{2}=2.822, \quad \mathrm{OR}=1.274, \quad p<0.10$. Similarly, the variable 'internal resources 2' (composed by delay in fulfilling bank obligations and management of receivables/payables indicators), positively affected business failure, $\chi^{2}=2.757$, $\mathrm{OR}=1.245, p<0.10$. Thus, the higher the constraints, the higher are chances business to terminate their activity. Regarding control variables, the full model revealed similar results with the baseline model. However, entrepreneurial experience resulted to be at the edge of acceptance as a significant factor $\left(\chi^{2}=2.591, \mathrm{OR}=0.964, p=0.107\right)$.

A test of the full model with all predictors against a constant-only model was statistically significant in baseline model $\left(\chi^{2}(11)=55.42, p<0.001\right)$, and full model $\left(\chi^{2}(14)=151.6, p<0.001\right)$ demonstrating that the predictors, as a set, significantly distinguished between firms which fail and those which did not. This is supported even by the results of Hosmer and Lemeshow test: baseline model $\left(\chi^{2}(8)=13.88, p>0.08\right)$ and full model $\left(\chi^{2}(8)=6.093, p>0.10\right)$. The effect size of the baseline model was 0.17 and 0.227, according to Cox and Snell and Nagelkerke R-squares, respectively. In the full model, these figures were 0.194 and 0.259 .

\section{DISCUSSION}

The current study has demonstrated useful findings regarding the determinants of business failure. The evidence revealed that business failure can be predicted through a set of factors originated from outside and within the organization along with firm characteristics. Furthermore, location (country) where firms operate and perform their activity was found to be significant in predicting business termination. In the following paragraphs are discussed these findings.

To follow rigour methodological procedures, initially, numerous indicators covering external and internal factors were grouped using principal component analysis with Varimax rotation. Afterwards, the emerged factors were tested whether they had internal consistency (reliability test) or 
not. Those factors that satisfied the assumption of Cronbach's alpha $(>0.7)$ were further analysed by logistic regression. Unfortunately, the factor which covered psychological motives and one factor dealing with internal resources were below this threshold, signalling their exclusion from further analysis. To have a better view of the effects of factors on business failure, hierarchical logistic regression with two steps was employed.

Factors originated from outside of the organization considered in this research were two: institutional environments and business cycles. The evidence revealed that institutional environment composed of two constraints (ecological and technological issues) do significantly predict firm termination. Findings showed that the higher the level of institutional constraints, the more likely a firm is to fail. This is consistent with prior studies (Vaillant \& Lafuente, 2007; García-Ramos et al., 2017; Karabag, 2019). This means that the greater the regulatory complexity and institutional requirements, the more likely a firm is to fail. Thus, evidence supports $\mathrm{H} 1$.

The state of the business cycle influence business activity. Indeed, the current study demonstrated that firms operating in times of growth phase of the business cycle were less likely to fail, as compared to those in establishment phase. However, the other phases of business cycles did not statistically predict business failure, as compared to establishment phase. This emphasizes the fact that when compared to establishment phase, neither growth nor decline phases do not diminish the chances a firm to fail. This goes in line with Bienkowska-Golasa's (2018) argument, which stresses out that in times of the economic growth, firm's internal resources are unused. Moreover, during the growth stage of business cycle, businesses have more opportunities to reorganize their processes, assets and human resources (Rauch \& Rijsdijk, 2013). In doing so, this category of firms has more possibilities to avoid their failure. Therefore, $\mathrm{H} 2$ was supported.

Along with external factors, internal ones were found to be significant in predicting business failure. Internal resources covered by a factor dealing with two kinds of difficulties (delay in fulfilling bank obligations, and management of receivables/payables). Poor leadership and mismanagement of internal resources (assets, liabilities, and human resources) can lead to business failure (Barney, 1991). Indeed, our data demonstrated that difficulties with internal resources increased the chances a business to fail. So, H3 was supported.

The number of years an individual works in business was expected to be negatively associated with business failure (Ucbasaran et al., 2010; Dias \& Teixeira, 2017; Rahman et al., 2018; Boso et al., 2019). This study's results are in line with prior research since it revealed a negative linkage between individual entrepreneurial experience and business failure. Individuals with many years in business have gain experience so as to adapt to different situation or factors that threat business continuance. Thus, our data support H5, but with a low level of confidence $(p=0.107)$.

Regarding firm characteristics, excluding firm age, the current research found that they significantly predict business failure. Hence, firm size negatively influences business failure, meaning that larger firms have fewer chances to fail, compared to their small counterparts. The finding concerning firm size support $\mathrm{H} 7$, which is consistent with 
prior studies (El Kalak \& Hudson, 2016; Martinez et al., 2019). On the other hand, this research fails to find any evidence of firm age significance on business failure, which leads to the rejection of H6. This insignificance relationship was reported even by other studies (Ucbasaran et al., 2010; Boso et al., 2019).

$\mathrm{H} 8$ assumes that the business commercial transactions (B2B, B2C and B2C\&B) influence business failure. The current research found evidence to support the idea that firms in the category of B2B are more likely to survive as compared to B2C. As Munoz and Kumar (2004) claimed, compared to $\mathrm{B} 2 \mathrm{C}$, firms having $\mathrm{B} 2 \mathrm{~B}$ commercial transactions have the advantage of knowing their buyers (other businesses), which gives the opportunities to adjust their strategies before the failure is irreversible.

Our data partly supported H9, since, in comparison to Serbian firms, those operating in Hungary reflected significantly fewer chances to fail. Nevertheless, Czech and Serbian firms did not differ in terms of predicting business failure. In the literature can be found both results: country affects and does not affect business failure. Hence, there are studies that found difference in entrepreneurial activity, including business failure, among countries (Dilli \& Westerhuis, 2018; Eling \& Jia, 2018; Tingbani et al., 2019). Nonetheless, there are other studies that argue that countries sharing similar cultural heritage and economic development do not have substantial differences in entrepreneurship or business risks (Belas et al., 2014; Çera et al., 2019a). Both Czech and Serbians share the same root: they are Slavic nations. This might be the reason why they showed similar results, but different from Hungarian firms.

\section{CONCLUSION}

Considering the benefits of entrepreneurship, scholars, government and public-policy advocates have a constant interest in understanding the business failure and what causes it. A better view over the determinants of business failure, can offer more opportunities to the above actors on adjusting existing strategies/policies or designing new ones aiming at boosting entrepreneurship. Accordingly, it is important to investigate psychological, situational and contextual factors that shape entrepreneurship (Ayyagari et al., 2007; Chowdhury et al., 2019) or can cause business failure (Jenkins \& McKelvie, 2016; Walsh \& Cunningham, 2016; Dias \& Teixeira, 2017). By knowing these, policies, strategies and different instruments can be designed and align to prevent business failure (Nair \& Blomquist, 2019).

The current research provides useful insights on business failure's determinants in the light of two major domains: determinist and voluntarist perspectives (Swaminathan, 1996; Van Gelder et al., 2007). These perspectives implicate numerous theories such as institutional theory, industry life cycle theory, resource-based view, emotive approach etc. Findings showed that these theories have the capacity to explain business failure in the context of three countries from Central Europe.

In the light of the determinist perspective, two theories were tested in this study (institutional, and industry life cycle theories) (North, 1990; Klepper, 1997). Consistent with them, this study demonstrated that institutional constraints increase the likelihood of business failure. Therefore, facing ecological and technological difficulties lead to business 
failure. In addition, findings showed that firms in times of growth stage of business cycle have fewer chances to fail. This means that the stage when firms face difficulties is important concerning business survival. These findings lead to the practical implications of the study. Policymakers should consider the level of regulatory framework as it positively affects business failure, and in accordance with the stage of business. As this study found, in times when firms are in the growth phase of business cycle can avoid their failure. From the public-policy advocates' point of view, it is useful to know the time when to apply low regulatory pressure.

Although the voluntarist perspective implicates several theories, only one was successfully tested in the current study: resources-based view (Barney, 1991). Facing difficulties such as delay in fulfilling bank obligations and management of receivables/payables can lead to business failure. These kinds of difficulties signal for poor management of internal resources (assets, capabilities, human resources, organizational processes). This finding leads to managerial implications of this research. Managers should design their processes in such a way that ensure no internal resources as a constraint or difficulty in doing business. Gaining knowledge on how to organize internal processes, including management of receivables and payables along with bank obligations, should be a priority for business owners/managers since, according to this paper's findings, their mismanagement can cause business failure.

From the managerial perspective, research on how to recover from a critical business situation is motivated. Learning by best practices can be useful for those organizations that are fighting to survive
(Nikolić et al., 2019). This can be a new window for further research. As discussed in the literature review, the consequences of failure is a new field of research, which is covered by the entrepreneurial perspective. Experiencing failure may be positive for individuals because they learn from it (Cope, 2011; Singh et al., 2015; Yamakawa et al., 2015). This could be considered as further research: studying the effect of failure and its cost on personal level in the context of the Central European countries.

Even though the aim of the research was achieved, yet there are some limitations. It is believed that a bigger number of observations could lead to more robust results, especially in terms of testing the theories' capacity to explain business failure. Although the literature identified psychological motives as an important driver of business survival or failure, this study failed to test it. Again, a bigger sample size might offer the possibilities to investigate the effect of this component on business failure.

\section{Acknowledgement}

This paper was supported by the International Visegrad Fund, project number 21820267, titled "How to prevent SMEs failure (Actions based on comparative analysis in Visegrad countries and Serbia)".

\section{References}

Abdesselam, R., Bonnet, J., RenouMaissant, P., \& Aubry, M. (2018). Entrepreneurship, economic development, and institutional environment: evidence from OECD countries. Journal of International Entrepreneurship, 16 (4), 504-546. 


\title{
ОБЈАШЫЕЊЕ ПОСЛОВНОГ НЕУСПЕХА ПОМОЋУ ДЕТЕРМИНИСТИЧКЕ И ВОЛУНТАРИСТИЧКЕ ПЕРСПЕКТИВЕ
}

\author{
Gentjan Çera, Jaroslav Belas, Eliska Zapletalikova
}

\section{Извод}

Циљ ове студије је да се истраже фактори који могу спречити пословни неуспех користећи заједно детерминистичку и волунтаристичку перспективу. Оба становишта имплицирају бројне теорије као што су институционална теорија, теорија животног циклуса индустрије, поглед на ресурсну основу, емотивни приступ итд. Ово истраживање је спроведено прикупљањем података на нивоу фирми путем анкете. Тренутна студија користи анализу главних компоненти и хијерархијску логистичку регресију за тестирање предложених хипотеза на оригиналном скупу података о малим и средњим предузећима (МСП) која послују у централној Европи. Резултати су показали да суочавање са институционалним ограничењима и унутрашњим тешкоћама може довести до пословног неуспеха. Предузећа у фази раста пословног циклуса имају мање шансе да не успеју у поређењу са њиховим колегама у фази оснивања. На индивидуалном нивоу, предузетничко искуство умањује пословни неуспех. Штавише, неуспеху су мање склоне веће фирме и они који послују као бизнис-бизнису (Б2Б). Тренутно истраживање доприноси обогаћивању литературе на том пољу нудећи доказе о томе како избећи неуспех. Овај рад пружа корисне перспективу и менаџерима и доносиоцима регулатива који су одговорни за осмишљавање политика и стратегија за јачање предузетништва.

Кључне речи: пословни неуспех, институционална ограничења, пословни циклус, интерни ресурси, психолошки мотиви, предузетничко искуство

Acs, Z.J., Estrin, S., Mickiewicz, T., \& Szerb, L. (2018). Entrepreneurship, institutional economics, and economic growth: an ecosystem perspective. Small Business Economics, 51 (2), 501-514.

Ayyagari, M., Beck, T., \& DemirgucKunt, A. (2007). Small and Medium Enterprises Across the Globe. Small Business Economics, 29 (4), 415-434.

Barney, J. (1991). Firm Resources and Sustained Competitive Advantage. Journal of Management, 17 (1), 99-120.

Belas, J., Machacek, J., Bartos, P., Hlawiczka, R., \& Hudakova, M. (2014). Business Risks and the Level of Entrepreneurial Optimism among SME in the Czech and Slovak Republic. Journal of
Competitiveness, 6 (2), 30-41.

Bienkowska-Golasa, W. (2018). Students' opinions on determinants of entrepreneurs' success or failure. In Proceedings of the 2018 International Conference "Economic Science for Rural Development". Jelgava. Latvia. 47, 36-41.

Blume, L. (2006). Local economic policies as determinants of the local business climate: Empirical results from a crosssection analysis among East German municipalities. Regional Studies, 40 (4), 321-333.

Bosma, N., Content, J., Sanders, M., \& Stam, E. (2018). Institutions, entrepreneurship, and economic growth in Europe. Small Business Economics, 51 (2), 
483-499.

Boso, N., Adeleye, I., Donbesuur, F., \& Gyensare, M. (2019). Do entrepreneurs always benefit from business failure experience? Journal of Business Research, 98, 370-379.

Brachert, M., Hyll, W., \& Titze, M. (2017). On the simultaneity bias in the relationship between risk attitudes, entry into entrepreneurship and entrepreneurial survival. Applied Economics Letters, 24 (7), 477-480.

Çera, G., Belás, J., \& Strnad, Z. (2019a). Important factors which predict entrepreneur's perception in business risk. Problems and Perspectives in Management, 17 (2), 415-429.

Çera, G., Breckova, P., Çera, E., \& Rozsa, Z. (2019b). The Effect of Business Enabling Policies, Tax Treatment, Corruption and Political Connections on Business Climate. Acta Polytechnica Hungarica, 16 (4), 113-132.

Çera, G., Cepel, M., Zakutna, S., \& Rozsa, Z. (2018). Gender differences in perception of the university education quality as applied to entrepreneurial intention. Journal of International Studies, 11 (3), 147-160.

Chowdhury, F., Audretsch, D.B., \& Belitski, M. (2019). Institutions and Entrepreneurship Quality. Entrepreneurship Theory and Practice, 43 (1), 51-81.

Cooper, A.C., \& Artz, K.W. (1995). Determinants of satisfaction for entrepreneurs. Journal of Business Venturing, 10 (6), 439-457.

Cope, J. (2011). Entrepreneurial learning from failure: An interpretative phenomenological analysis. Journal of Business Venturing, 26 (6), 604-623.

Dheer, R.J.S. (2017). Cross-national differences in entrepreneurial activity: role of culture and institutional factors. Small Business Economics, 48 (4), 813-842.

Dias, A., \& Teixeira, A.A.C. (2017). The anatomy of business failure. European Journal of Management and Business Economics, 26 (1), 2-20.

Dilli, S., \& Westerhuis, G. (2018). How institutions and gender differences in education shape entrepreneurial activity: a cross-national perspective. Small Business Economics, 51 (2), 371-392.

Douhan, R., \& Henrekson, M. (2010). Entrepreneurship and second-best institutions: going beyond Baumol's typology. Journal of Evolutionary Economics, 20 (4), 629-643.

El Kalak, I., \& Hudson, R. (2016). The effect of size on the failure probabilities of SMEs: An empirical study on the US market using discrete hazard model. International Review of Financial Analysis, 43, 135-145.

Eling, M., \& Jia, R. (2018). Business failure, efficiency, and volatility: Evidence from the European insurance industry. International Review of Financial Analysis, 59, 58-76.

European Commission. (2018). 2018 SBA Fact Sheet. Retrieved from http://ec.europa.eu/growth/smes/businessfriendly-environment/performance-review/

Fabrigar, L.R., \& Wegener, D.T. (2011). Exploratory Factor Analysis. Oxford University Press. New York, NY.

Falkner, E.M., \& Hiebl, M.R.W. (2015). Risk management in SMEs: a systematic review of available evidence. The Journal of Risk Finance, 16 (2), 122-144.

Gagoitseope, P.K., \& Pansiri, J. (2012). Evaluation of Critical Success Factors for Developing Small and Medium-Sized Enterprises in Botswana. Journal of African Business, 13 (1), 51-61.

García-Ramos, C., Gonzalez-Alvarez, N., 
\& Nieto, M. (2017). Institutional framework and entrepreneurial failure. Journal of Small Business and Enterprise Development, 24 (4), 716-732.

Guerrero, M., Urbano, D., \& Fayolle, A. (2016). Entrepreneurial activity and regional competitiveness: evidence from European entrepreneurial universities. The Journal of Technology Transfer, 41 (1), 105-131.

Hair, J.F., Black, W.C., Babin, B.J., \& Anderson, R.E. (2014). Multivariate Data Analysis (7th Edition). Harlow: Pearson Education Limited.

Hosmer, D.W., Lemeshow, S., \& Sturdivant, R.X. (2013). Applied logistic regression. (3rd ed.). Wiley.

Iwanicz-Drozdowska, M., Jackowicz, K., \& Kozłowski, Ł. (2018). SMEs’ near-death experiences. Do local banks extend a helping hand? Emerging Markets Review, 37, 47-65.

Jenkins, A., \& McKelvie, A. (2016). What is entrepreneurial failure? Implications for future research. International Small Business Journal: Researching Entrepreneurship, 34 (2), 176-188.

Karabag, S.F. (2019). Factors impacting firm failure and technological development: A study of three emerging-economy firms. Journal of Business Research, 98, 462-474.

Khelil, N. (2016). The many faces of entrepreneurial failure: Insights from an empirical taxonomy. Journal of Business Venturing, 31 (1), 72-94.

Klepper, S. (1997). Industry Life Cycles. Industrial and Corporate Change, 6 (1), 145-182.

Kliestik, T., Misankova, M., Valaskova, K., \& Svabova, L. (2018). Bankruptcy Prevention: New Effort to Reflect on Legal and Social Changes. Science and Engineering Ethics, 24 (2), 791-803.

Kücher, A., \& Feldbauer-Durstmüller, B. (2019). Organizational failure and decline -
A bibliometric study of the scientific frontend. Journal of Business Research, 98, 503-516.

Lačný, M., Lukáčová, J., \& Kovalčíková, I. (2018). Specifics of introducing a code of ethics into the academic environment. Ethics \& Bioethics (in Central Europe), 8 (1-2), 91-108.

Martinez, M.G., Zouaghi, F., Marco, T.G., \& Robinson, C. (2019). What drives business failure? Exploring the role of internal and external knowledge capabilities during the global financial crisis. Journal of Business Research, 98, 441-449.

Mellahi, K., \& Wilkinson, A. (2004). Organizational failure: a critique of recent research and a proposed integrative framework. International Journal of Management Reviews, 5-6 (1), 21-41.

Munoz, T., \& Kumar, S. (2004). Brand metrics: Gauging and linking brands with business performance. Journal of Brand Management, 11 (5), 381-387.

Nair, S., \& Blomquist, T. (2019). Failure prevention and management in business incubation: practices towards a scalable business model. Technology Analysis \& Strategic Management, 31 (3), 266-278.

Nikolić, N., Jovanović, I., Nikolić, Đ., Mihajlović, I., \& Schulte, P. (2019). Investigation of the Factors Influencing SME Failure as a Function of Its Prevention and Fast Recovery after Failure. Entrepreneurship Research Journal, 9 (3), $1-21$.

North, D.C. (1990). Institutions, institutional change, and economic performance. Cambridge University Press. New York.

Pansiri, J., \& Temtime, Z.T. (2010). Linking firm and managers' characteristics to perceived critical success factors for innovative entrepreneurial support. Journal 
of Small Business and Enterprise Development, 17 (1), 45-59.

Pinho, J.C. (2017). Institutional theory and global entrepreneurship: exploring differences between factor- versus innovation-driven countries. Journal of International Entrepreneurship, 15 (1), 56-84.

Rahman, A., Rozsa, Z., \& Cepel, M. (2018). Trade Credit and Bank Finance Evidence from the Visegrad Group. Journal of Competitiveness, 10 (3), 132-148.

Rauch, A., \& Rijsdijk, S.A. (2013). The Effects of General and Specific Human Capital on Long-Term Growth and Failure of Newly Founded Businesses. Entrepreneurship Theory and Practice, 37 (4), 923-941.

Raza, A., Muffatto, M., \& Saeed, S. (2018). The influence of formal institutions on the relationship between entrepreneurial readiness and entrepreneurial behaviour. Journal of Small Business and Enterprise Development, 26 (1), 133-157.

Sauka, A., \& Welter, F. (2014). Determinants of Business Insolvencies During Economic Growth and Recession in Latvia. Journal of Baltic Studies, 45 (3), 375-396.

Shepherd, D.A., Wennberg, K., Suddaby, R., \& Wiklund, J. (2019). What Are We Explaining? A Review and Agenda on Initiating, Engaging, Performing, and Contextualizing Entrepreneurship. Journal of Management, 45 (1), 159-196.

Singh, S., Corner, P.D., \& Pavlovich, K. (2015). Failed, not finished: A narrative approach to understanding venture failure stigmatization. Journal of Business Venturing, 30 (1), 150-166.

Sobel, R.S. (2008). Testing Baumol: Institutional quality and the productivity of entrepreneurship. Journal of Business
Venturing, 23 (6), 641-655.

Solaja, O.M., Idowu, F.E., \& James, A.E. (2016). Exploring the relationship between leadership communication style, personality trait and organizational productivity. Serbian Journal of Management, 11 (1), 99-117.

Stacho, Z., Stachová, K., Hudáková, M., \& Stasiak-Betlejewska, R. (2017). Employee adaptation as key activity in human resource management upon implementing and maintaining desired organisational culture. Serbian Journal of Management, 12(2), 303313.

Stam, E. (2009). Why Butterflies Don't Leave: Locational Behavior of Entrepreneurial Firms. Economic Geography, 83 (1), 27-50.

Stevens, J.P., \& Pituch, K A. (2015). Applied Multivariate Statistics for the Social Sciences: Analyses with SAS and IBM's SPSS (6th ed.). Routledge. New York.

Swaminathan, A. (1996). Environmental conditions at founding and organizational mortality: A trial-by-fire model. Academy of Management Journal, 39 (5), 1350-1377.

Tabachnick, B.G., \& Fidell, L.S. (2013). Using multivariate statistics (6th ed.). Pearson Education. Boston.

Tingbani, I., Okafor, G., Tauringana, V., \& Zalata, A.M. (2019). Terrorism and countrylevel global business failure. Journal of Business Research, 98, 430-440.

Ucbasaran, D., Shepherd, D.A., Lockett, A., \& Lyon, S.J. (2013). Life After Business Failure: The Process and Consequences of Business Failure for Entrepreneurs. Journal of Management, 39 (1), 163-202.

Ucbasaran, D., Westhead, P., Wright, M., \& Flores, M. (2010). The nature of entrepreneurial experience, business failure and comparative optimism. Journal of Business Venturing, 25 (6), 541-555.

Vaillant, Y., \& Lafuente, E. (2007). Do 
different institutional frameworks condition the influence of local fear of failure and entrepreneurial examples over entrepreneurial activity? Entrepreneurship and Regional Development, 19 (4), 313-337.

Valaskova, K., Kliestik, T., \& Kovacova, M. (2018). Management of financial risks in Slovak enterprises using regression analysis. Oeconomia Copernicana, 9 (1), 105-121.

Van Gelder, J.L., De Vries, R.E., Frese, M., \& Goutbeek, J.P. (2007). Differences in psychological strategies of failed and operational business owners in the Fiji Islands. Journal of Small Business Management, 45 (3), 388-400.

Walsh, G.S., \& Cunningham, J.A. (2016). Business Failure and Entrepreneurship: Emergence, Evolution and Future Research. Foundations and Trends ${ }^{\circledR}$ in Entrepreneurship, 12 (3), 163-285.

Wennekers, S., van Wennekers, A., Thurik, R., \& Reynolds, P. (2005). Nascent Entrepreneurship and the Level of Economic Development. Small Business Economics, 24 (3), 293-309.

Yamakawa, Y., Peng, M.W., \& Deeds, D.L. (2015). Rising From the Ashes: Cognitive Determinants of Venture Growth After Entrepreneurial Failure. Entrepreneurship Theory and Practice, 39 (2), 209-236. 